\title{
Hubungan Kebisingan Terhadap Tekanan Darah Pada Pekerja Lapangan PT. Gapura Angkasa Di Bandar Udara Sam Ratulangi, Manado.
}

\author{
${ }^{1}$ Shinly Suzana Montolalu \\ ${ }^{2}$ Wenny Supit \\ ${ }^{2}$ Vennetia R. Danes \\ ${ }^{1}$ Kandidat Skripsi Fakultas Kedokteran Universitas Sam Ratulangi Manado \\ ${ }^{2}$ Bagian Fisika Fakultas Kedokteran Universitas Sam Ratulangi Manado \\ Email: shinlymontolalu@ymail.com
}

\begin{abstract}
Environmental noise is unwanted sound, which induces physiological alteration on individuals exposed to it. The effect of noise in causing health disorder depends on the intensity, frequency and length of exposure to noise. The purpose of this research is to determine the correlation between noise and blood pressure on PT. Gapura Angkasa field workers in Sam Ratulangi Airport Manado. The research methodeology used is observational study using cross sectional design. The research was conducted between October to December 2013. Subjects are 30 field workers of PT. Gapura Angkasa in Sam Ratulangi Airport Manado selected through questionnaire, inclusion and exclusion criteria. Data analysis performed by Fisher Exact Tests using SPSS.

The result showed that there are 18 people (60\%) with increased systolic blood pressure and 14 people (46,7\%) with increased diastolic blood pressure exposed by noise intensity over $85 \mathrm{~dB}$. There are 3 people (10\%) with increased systolic blood pressure and only 1 people with increased diastolic blood pressure exposed by noise intensity under $85 \mathrm{~dB}$. In conclusion, it shows that there are increasing of systolic blood pressure $(p=0,032)$ and diastolic blood pressure ( $\mathrm{p}=0,018$ ) significantly.
\end{abstract}

Keywords: Systolic, Diastolic, Blood Pressure, Noise Intensity

\begin{abstract}
Abstrak
Bising lingkungan merupakan suara yang tidak dikehendaki yang dapat menyebabkan perubahan fisiologis pada setiap individu yang terpapar bising tersebut. Pengaruh kebisingan terhadap timbulnya gangguan kesehatan dapat dipengaruhi oleh beberapa faktor yaitu intensitas, frekuensi dan lamanya terpapar kebisingan tersebut. Tujuan penelitian ini untuk mengetahui apakah terdapat hubungan kebisingan terhadap tekanan darah pada pekerja yang terpajan kebisingan di Bandar Udara Sam Ratulangi Manado. Metode penelitian yang digunakan adalah studi Observasional dengan desain cross sectional, yang dilaksanakan pada bulan Oktober sampai Desember. Subjek penelitian adalah 30 pekerja lapangan PT. Gapura Angkasa di Bandar
\end{abstract}


Udara Sam Ratulangi Manado yang dipilih melalui kuesioner, kriteria inklusi dan eksklusi. Analisis data dilakukan uji statistic Fisher Exact Test dengan menggunakan SPSS.

Hasil penelitian menunjukan bahwa terdapat 18 orang (60\%) mengalami peningkatan tekanan darah sisitolik dan 14 orang (46,7\%) mengalami peningkatan tekanan darah diastolik yang terpapar intensitas bising $>85 \mathrm{~dB}$. Terdapat 3 orang (10\%) mengalami peningkatan tekanan darah sisitolik dan hanya 1 orang mengalami peningkatan tekanan darah diastolik yang terpapar dengan intensitas bising $<85 \mathrm{~dB}$. Kesimpulan, hal itu menunjukan peningkatan tekanan darah sistolik ( $\mathrm{p}=0,032)$ dan tekanan darah diastolik $(\mathrm{p}=0,018)$ yang berarti $\mathrm{p}<0,05$.

Kata Kunci: Sistolik, Diastolik, Tekanan Darah, Intensitas Bising

Bising didefinisikan sebagai bunyi yang tidak diinginkan dari usaha atau kegiatan dalam tingkat dan waktu tertentu yang dapat menimbulkan gangguan kesehatan manusia dan kenyamanan lingkungan (Keputusan Menteri Lingkungan Hidup No. 48 Tahun 1996). ${ }^{1,6}$ Salah satu sumber bising yang dapat mengganggu kesehatan adalah mesin pesawat terbang. Bising pesawat terbang ini termasuk dalam jenis bising terputus-putus (intermiten) yang tidak terjadi secara terus menerus, melainkan ada periode relatif tenang. ${ }^{2}$

Hubungan antara kebisingan dengan kemungkinan timbulnya gangguan terhadap kesehatan sangat dipengaruhi oleh beberapa faktor yaitu intensitas kebisingan, frekuensi kebisingan dan lamanya seseorang berada di tempat atau sumber bunyi tersebut, baik dari hari ke hari ataupun seumur hidupnya. Beberapa penelitian yang dilakukan, menemukan bahwa kebisingan memberikan efek buruk pada kesehatan, salah satunya pengaruh bising terhadap peningkatan tekanan darah. ${ }^{3}$

Kebisingan direspon oleh otak yang merasakan pengalaman ini sebagai ancaman atau stress yang kemudian berhubungan dengan pengeluaran hormon stress seperti epinepfrin, norepinefrin dan kortisol. Stress akan mempengaruhi sistim saraf yang kemudian berpengaruh pada detak jantung, akan berakibat perubahan tekanan darah. ${ }^{3}$

Tekanan darah adalah tekanan di dalam pembuluh darah ketika jantung memompakan darah ke seluruh tubuh. ${ }^{4}$ Meningkatnya tekanan darah dapat terjadi melalui beberapa cara seperti: jantung memompa lebih kuat, arteri besar kehilangan kelenturannya dan menjadi kaku atau bertambahnya cairan dalam sirkulasi bisa menyebabkan meningkatnya tekanan darah. $^{5}$

Penelitian yang dilakukan oleh Eny Hastuti meneliti efek kebisingan pada 60 pekerja di Bandara Ahmad Yani Semarang. Dia menemukan bahwa kebisingan kurang atau sama dengan 85 dBA sebanyak 26,7\% pekerja mengalami kenaikan tekanan darah sistolik dan 33\% pekerja mengalami kenaikan darah diastolik. $^{3}$

Rosidah melakukan studi kejadian akibat hipertensi pada wanita yang tinggal di sekitar lintasan kereta api di Kota Semarang. Ia mendapatkan hasil bahwa kejadian hipertensi lebih banyak terjadi pada kelompok responden yang tinggal di daerah dengan intensitas bising lebih dari nilai ambang batas prevalensinya yaitu 52,4\% dan pada kelompok daerah dengan 
kebisingan kurang dari nilai ambang batas prevalensinya yaitu $50 \%{ }^{6}$

\section{METODE PENELITIAN}

Jenis penelitian yang digunakan adalah observasional dengan desain cross sectional. Waktu penelitian dilakukan bulan Oktober Desember 2013. Tampat penelitian dilakukan di Bandar Udara Sam Ratulangi Manado. Populasi adalah semua pekerja lapangan di Bandar Udara Sam Ratulangi Manado yang kemudian sampel diambil dengan memenuhi kriteria inklusi dan eksklusi serta pengisian kuesioner. Variabel penelitian terdiri dari dua variable yaitu variabel bebas (independent) yaitu bising dan variabel terikat (dependent) yaitu tekanan darah.

Jenis pengambilan data terdiri dari 2 yaitu data primer yang diperoleh dari kuesioner, pengukuran tekanan darah sebelum dan sesudah bekerja dan data sekunder yang diperoleh dari penelusuran data-data yang diambil dari Bandar Udara Sam Ratulangi Manado. Selanjutnya, hasil penelitian dianalisis dan diolah dengan uji fisher exact yang menggunakan program SPP versi 16.0

\section{HASIL PENELITIAN}

Pekerja di Bandar Udara Sam Ratulangi kebanyakan bekerja dalam dua shift yaitu shift pagi pada pukul 05.00 - 13.00 dan shift sore pukul 13.00 - 21.00. Seluruh sampel berjumlah 30 responden dengan tingkat kebisingan yang didapatkan sebesar $75 \mathrm{~dB}$ di daerah sekitar lapangan, $85 \mathrm{~dB}$ saat pesawat dipanaskan dan $95 \mathrm{~dB}$ saat pesawat mendarat.
Berdasarkan analisis univariat karakteristik responden dalam penelitian ini meliputi umur, bagian/unit kerja, durasi ratarata bekerja dalam sehari, penggunaan alat pelindung telinga, tekanan darah sistolik sebelum dan sesudah terpapar bising, serta tekanan darah diastolik sebelum dan sesudah terpapar bising. Untuk memperoleh gambaran distribusi menurut karakteristik responden dapat dilihat pada tabel berikut:

Tabel 1. Distribusi menurut umur

\begin{tabular}{lcc}
\hline \multicolumn{1}{c}{ Umur } & $\mathrm{n}$ & $\%$ \\
\hline $\mathbf{2 0}-\mathbf{3 0}$ & 9 & 30.0 \\
$\mathbf{3 1} \mathbf{- 4 0}$ & 11 & 36.7 \\
$\mathbf{4 1}-\mathbf{5 0}$ & 9 & 30.0 \\
$>\mathbf{5 0}$ & 1 & 3.3 \\
\hline Total & 30 & 100 \\
\hline
\end{tabular}

Tabel satu menunjukan bahwa jumlah responden terbanyak berumur antara 31 - 40 tahun yakni sebanyak 11 responden (presentase 36,7\%) dibanding dengan umur 20 - 30 tahun yang berjumlah sama dengan umur 41 - 50 tahun yakni sebanyak 9 responden (presentase 30\%) dan umur $>50$ tahun yang berjumlah 1 responden (presentase 3,3\%).

Tabel 2. Distribusi menurut bagian/unit kerja.

\begin{tabular}{lcc}
\hline $\begin{array}{c}\text { Bagian/Unit } \\
\text { Kerja }\end{array}$ & $\mathrm{n}$ & $\%$ \\
\hline Loading & 8 & 26.7 \\
Security & 3 & 10.0 \\
Operation & 11 & 36.7 \\
Pasasi & 5 & 16.7 \\
Cleaning & 3 & 10.0 \\
\hline Total & 30 & 100 \\
\hline
\end{tabular}

Tabel 2 menunjukan bahwa jumlah responden terbanyak bekerja di unit kerja 
bagian operation yakni sebanyak 11 responden (presentase 36,7\%), sedangkan bagian lain seperti bagian loading sebanyak 8 responden (presentase 26,7\%), bagian pasasi sebanyak 5 responden (presentase $16,7 \%$ ), bagian security dan cleaning sebanyak 3 responden (presentase 10\%).

Tabel 3. Distribusi menurut durasi ratarata bekerja dalam sehari.

\begin{tabular}{lcc}
\hline $\begin{array}{c}\text { Durasi rata-rata } \\
\text { bekerja dalam } \\
\text { sehari }\end{array}$ & $\mathrm{n}$ & $\%$ \\
\hline $\mathbf{8}$ jam & 0 & 0 \\
$>\mathbf{8}$ jam & 30 & 100 \\
\hline Total & 30 & 100 \\
\hline
\end{tabular}

Tabel 3 didapatkan seluruh pekerja bekerja $>8$ jam dalam sehari dengan presentase $100 \%$.

Tabel 4. Distribusi menurut penggunaan alat pelindung telinga

\begin{tabular}{lcc}
\hline $\begin{array}{l}\text { Penggunaan alat } \\
\text { pelindung telinga }\end{array}$ & $\mathrm{n}$ & $\%$ \\
\hline Ya & 21 & 70.0 \\
Tidak & 9 & 30.0 \\
\hline Total & 30 & 100 \\
\hline
\end{tabular}

Tabel 4 menunjukan bahwa sebanyak 21 responden dengan presentase $70 \%$ memakai alat pelindung telinga saat bekerja dan sebanyak 9 responden dengan presentase $30 \%$ tidak memakai alat pelindung telinga saat bekerja.
Tabel 5. Distribusi tekanan darah sistolik sebelum terpapar bising.

\begin{tabular}{lcc}
$\begin{array}{c}\text { Tekanan darah sistolik } \\
\text { sebelum terpapar bising } \\
\text { (mmHg) }\end{array}$ & $\mathrm{n}$ & $\%$ \\
\hline $\mathbf{1 0 0}$ & 3 & 10.0 \\
$\mathbf{1 1 0}$ & 8 & 26.7 \\
$\mathbf{1 2 0}$ & 11 & 36.7 \\
$\mathbf{1 3 0}$ & 6 & 20.0 \\
$\mathbf{1 4 0}$ & 2 & 6.7 \\
\hline Total & 30 & 100 \\
\hline
\end{tabular}

Tabel 5 menunjukan hasil pengukuran tekanan darah sistolik sebelum terpapar bising, ditemukan 2 responden (6,7\%) dengan nilai paling tinggi yaitu $140 \mathrm{mmHg}$ dan 3 responden (10\%) dengan nilai paling rendah yaitu $100 \mathrm{mmHg}$.

Tabel 6. Distribusi tekanan darah sistolik sesudah terpapar bising.

\begin{tabular}{lcc}
$\begin{array}{c}\text { Tekanan darah sistolik } \\
\text { sesudah terpapar bising } \\
\text { (mmHg) }\end{array}$ & $\mathrm{n}$ & $\%$ \\
\hline $\mathbf{1 1 0}$ & 1 & 3.3 \\
$\mathbf{1 2 0}$ & 15 & 50.0 \\
$\mathbf{1 3 0}$ & 7 & 23.3 \\
$\mathbf{1 4 0}$ & 7 & 23.3 \\
\hline Total & 30 & 100 \\
\hline
\end{tabular}

Tabel 6 menunjukan tekanan darah sistolik sesudah terpapar bising, ditemukan 1 responden (3,3\%) dengan nilai terendah 110 mmHg dan 7 responden dengan nilai tertinggi yakni $140 \mathrm{mmHg}$. Sedangkan yang paling banyak ditemukan 15 responden pada nilai $120 \mathrm{mmHg}$. 
Tabel 7. Distribusi tekanan darah diastolik sebelum terpapar bising.

\begin{tabular}{lcc}
$\begin{array}{l}\text { Tekanan darah diastolik } \\
\text { sebelum terpapar bising } \\
\text { (mmHg) }\end{array}$ & $\mathrm{n}$ & $\%$ \\
\hline $\mathbf{6 0}$ & 6 & 20.0 \\
$\mathbf{7 0}$ & 7 & 23.3 \\
$\mathbf{8 0}$ & 16 & 53.3 \\
$\mathbf{9 0}$ & 1 & 3.3 \\
\hline Total & 30 & 100 \\
\hline
\end{tabular}

Tabel 7 menunjukan hasil pengukuran tekanan darah diastolik sebelum terpapar bising, ditemukan 6 responden (20\%) dengan nilai terendah yakni $60 \mathrm{mmHg}$ dan 1 responden dengan nilai tertinggi yakni 90 mmHg. Sedangkan yang paling banyak yakni 16 responden (53,3\%) dengan nilai 80 mmHg.

Tabel 8. Distribusi tekanan darah diastolik sesudah terpapar bising.

\begin{tabular}{lcc}
$\begin{array}{c}\text { Tekanan darah diastolik } \\
\text { sesudah terpapar bising } \\
\text { (mmHg) }\end{array}$ & $\mathrm{n}$ & $\%$ \\
\hline $\mathbf{6 0}$ & 1 & 3.3 \\
$\mathbf{7 0}$ & 9 & 30.0 \\
$\mathbf{8 0}$ & 11 & 36.7 \\
$\mathbf{9 0}$ & 9 & 30.0 \\
\hline Total & 30 & 100 \\
\hline
\end{tabular}

Tabel 8 menunjukan hasil tekanan darah diastolik sesudah terpapar bising, ditemukan hanya 1 responden (3,3\%) dengan nilai terendah yakni $60 \mathrm{mmHg}$ dan 9 responden (30\%) dengan nilai tertinggi yakni 90 mmHg. Sedangkan paling banyak yakni 11 responden (36,7\%) dengan nilai $80 \mathrm{mmHg}$.

Dari hasil pengukuran intensitas bising menggunakan alat Sound Level Meter didapatkan hasil terbanyak adalah para pekerja yang bekerja pada tingkat bising > $85 \mathrm{~dB}$ yaitu dengan jumlah 22 responden
(73,3\%). Pekerja yang bekerja pada tingkat bising $\leq 85 \mathrm{~dB}$ berjumlah 8 responden (26,7\%).

Tabel 9. Distribusi menurut intensitas bising

\begin{tabular}{lcc}
\hline \multicolumn{1}{c}{ Intensitas bising } & $\mathrm{n}$ & $\%$ \\
\hline$\leq \mathbf{8 5} \mathbf{~ d B}$ & 8 & 26.7 \\
$>\mathbf{8 5} \mathbf{~ d B}$ & 22 & 73.3 \\
\hline Total & 30 & 100 \\
\hline
\end{tabular}

Berdasarkan analisis bivariat menggunakan tabulasi silang yang bertujuan untuk melihat hubungan antara variable bebas dan variable terikat. Uji statistik yang digunakan yaitu Fisher Exact Test, karena nilai sampel yang kurang dari 40 atau 20 40 dengan syarat nilai harapan kurang dari 5 dan tidak memungkinkan menggunakan Chi-Square. Nilai Uji Fisher yang didapatkan yaitu $\mathrm{p}=0,032$ untuk hubungan intensitas bising terhadap tekanan darah sistolik dan $\mathrm{p}=0,018(\mathrm{p}<0,05)$ untuk hubungan intensitas bising terhadap tekanan darah diastolik $(\mathrm{p}<0,05)$.

\section{PEMBAHASAN}

Kebisingan direspon oleh otak yang merasakan pengalaman ini sebagai ancaman atau stress yang kemudian berhubungan dengan pengeluaran hormon stress seperti epinepfrin, norepinefrin dan kortisol. Stress akan mempengaruhi sistim saraf yang kemudian berpengaruh pada detak jantung, akan berakibat perubahan tekanan darah. Hal ini sesuai dengan teori yang dikemukakan dalam hukum Poiseuille yaitu kecepatan aliran darah berbanding lurus dengan pangkat empat dari radius pembuluh darah. Jadi, diameter pembuluh darah mempunyai peran paling besar dalam 
menentukan konduktans/kecepatan aliran darah. Saat terjadi vasokonstriksi pembuluh darah menyebabkan jari-jari pembuluh darah menyempit menyebabkan berkurangnya aliran darah. Oleh sebab itu, jantung bekerja lebih keras untuk memompa darah, sehingga menyebabkan tekanan akan lebih meningkat. ${ }^{3,8}$

Penelitian ini mengikutsertakan 30 pekerja lapangan di Bandar Udara Sam Ratulangi Manado yang bekerja di bagian/unit kerja yang berbeda-beda. Dalam penelitian, ditemukan paling banyak pekerja yang bekerja di bagian operasional sebanyak 11 responden (36,7\%) dan paling sedikit sebanyak 3 responden (10\%) yang bekerja di bagian cleaning.

Usia responden yang paling banyak sekitar umur 31-40 tahun berjumlah 11 responden (36,7\%). Sedangkan hanya 1 responden $(3,3 \%)$ yang berumur $>50$ tahun. Durasi rata-rata bekerja dalam sehari adalah 12 jam, artinya sudah melebihi standar kebisingan berdasarkan Surat Keputusan Menteri Tenaga Kerja No. Kep.51/MEN/1999 tentang perlindungan tenaga kerja, waktu kerja 8 jam per hari atau 40 jam per minggu. ${ }^{7,9}$

Dalam penelitian ini diambil 30 orang pekerja yang tidak memiliki riwayat hipertensi sebelumnya dan lama bekerja yang bervariatif diatas 2 tahun. Sebanyak 21 responden (70\%) yang memakai alat pelindung diri saat bekerja dan sisanya 9 responden (30\%) tidak memakai alat pelindung diri saat bekerja

Dari data di atas terlihat bahwa pekerja yang terpajan kebisingan lebih dari $85 \mathrm{~dB}$, sebanyak 18 responden (60\%) mengalami peningkatan tekanan darah sistolik dan 4 responden (13,3\%) tidak mengalami peningkatan tekanan darah sistolik. Sedangkan sebanyak 14 responden (46,7\%) mengalami peningkatan tekanan darah diastolik dan 8 responden (26,7\%) tidak mengalami peningkatan tekanan darah diastolik.

Pada intensitas kebisingan yang kurang dari $85 \mathrm{~dB}$, ditemukan sebanyak 3 responden (10\%) yang mengalami peningkatan tekanan darah sistolik dan 5 responden (16,7\%) tidak mengalami peningkatan tekanan darah sistolik. Sedangkan hanya 1 responden (3,3\%) yang mengalami peningkatan tekanan darah diastolik dan 7 responden (23,3\%) yang tidak mengalami peningkatan tekanan darah diastolik.

Berdasarkan hasil analisis data dengan menggunakan Fisher Exact Test didapatkan hasil $\mathrm{p}=$ 0,032 untuk hubungan intensitas bising terhadap tekanan darah sistolik dan $\mathrm{p}$ $=0,018$ untuk hubungan intensitas bising terhadap tekanan darah diastolik dan keduanya menunjukan hasil yang signifikan $(p \leq 0,05)$. Hasil ini sejalan dengan penelitian yang dilakukan oleh Dinar Hartanto terhadap karyawan Unit Compressor PT. Indo Acidatama, Karanganyar didapatkan hubungan antara kebisingan dengan tekanan darah dengan nilai $\mathrm{p}=0,000(\leq 0,05){ }^{9}$

\section{KESIMPULAN DAN SARAN}

Terdapat hubungan bising terhadap tekanan darah pada pekerja dengan prevalensi kenaikan tekanan darah sistolik pada intensitas bising $>85 \mathrm{~dB}$ sebesar 66,6\%. Sedangkan prevalensi kenaikan tekanan darah diastolik pada intensitas 
bising $\leq 85 \mathrm{~dB}$ sebesar $63,3 \%$. Dari hasil analisis bivariat data yang diperoleh melalui uji fisher exact menunjukan nilai $\mathrm{p}=0,032$ $(\mathrm{p}<0,05)$ untuk hubungan intensitas bising terhadap tekanan darah sistolik dan $\mathrm{p}=$ $0,018(\mathrm{p}<0,05)$ untuk hubungan intensitas bising terhadap tekanan darah diastolik. Hal ini menunjukan kedua data ini signifikan.

Perlu dilakukan pemeriksaan tekanan darah secara periodik terhadap tenaga kerja untuk pemantauan dan pengendalian, adanya pengawasan penggunaan alat pelindung diri, serta dapat dilakukan penyuluhan dan sosialisasi tentang dampak kebisingan terhadap tekanan darah kepada para pekerja.

\section{DAFTAR PUSTAKA}

\section{Keputusan Menteri Negara Lingkungan Hidup No. 48 Tahun 1996}

2. Buchari. 2007. Kebisingan Industri dan Hearing Conservation Program. Diunduh tanggal 27 Oktober 2013 dari:

library.usu.ac.id/download/ft/07002749. pdf

3. Hastuti E. Pengaruh Bising Terhadap Kenaikan Tekanan Darah Pada Pekerja di Bandara Ahmad Yani Semarang [Tesis]. [Semarang]: Universitas Diponegoro; 2004.

4. Babba J. Hubungan Antara Intensitas Kebisingan Di Lingkungan Kerja Dengan Peningkatan Tekanan Darah [Tesis]. [Semarang]: Universitas Diponegoro; 2007.

5. Hernawati. Sistem Renin-AngiotensinAldosteron. Diunduh tanggal 25 Oktober 2013 dari:
http://file.upi.edu/Direktori/FPMIPA/JU R._PEND._BIOLOGI/19700331199702 2-HERNAWATI/FILE 6.pdf

6. Rosidah R. Studi Kejadian Hipertensi Akibat Bising Pada Wanita Yang Tinggal Di Sekitar Lintasan Kereta Api [Tesis]. [Semarang]: Universitas Diponegoro; 2004.

7. Muchsin, Haryono, Rosyidah. Hubungan karakteristik pekerja dengan tekanan darah pekerja wanita terpapar bising shift pagi di bagian weaving (tenun) "Agung Saputra Tex". Jurnal Kesehatan Masyarakat. 2010;4:155

8. Susanto Y. Pengaruh Olahraga Ringan Terhadap Memori Jangka Pendek Pada Wanita Dewasa. Maranatha Journal. 2009;8:146

9. Hartanto D. Hubungan Kebisingan Dengan Tekanan Darah Pada Karyawan Unit Compressor PT. Indo Acidatama [Laporan Khusus]. [Surakarta]: Universitas Sebelas Maret; 2011. 